\title{
Bhutanese Teachers' and Students' Perceptions about Environmental Issues in Bhutan
}

\author{
Kishore Mongar ${ }^{1,2 *}$
}

\author{
1 University of New England, AUSTRALIA \\ 2 Samtse College of Education, Royal University of Bhutan, BHUTAN \\ *Corresponding Author: kthapa05@gmail.com
}

Citation: Mongar, K. (2022). Bhutanese teachers' and students' perceptions about environmental issues in Bhutan. Interdisciplinary Journal of Environmental and Science Education, 18(1), e2263. https://doi.org/10.21601/ijese/11363

\begin{abstract}
ARTICLE INFO ABSTRACT
Received: $\quad$ Bhutan aspires to achieve Gross National Happiness (GNH) through sustainable environmental 18 November 2021 conservation and socioeconomic development. However, the country is facing increasing environmental challenges. Education is considered to be a key component in a range of efforts to

Accepted:

3 August 2021 remediate current environmental threats in Bhutan. As part of this agenda, the optional school subject of Environmental Science was introduced in 2015 for Classes IX-XII with the aim of equipping young people with the knowledge and values to protect the environment and promote sustainable and equitable use of natural resources in the pursuit of GNH. This paper focuses on the qualitative aspect of a broader mixed-method research project that explored the effective implementation of Environmental Science in secondary schools in the Samtse region of Bhutan. This study answers the research question: "What are teachers' and students' views about environmental problems in Bhutan?" Drawing on interviews of 14 teachers and 194 students engaged in Environmental Science, the results showed that participants were aware of various environmental problems; however, they lacked knowledge and awareness about climate change issues in Bhutan. The results suggest the need for more emphasis on climate change education in Bhutan. The student participants believed in collectivism to address the environmental challenges, indicating a strong cultural influence that schools could leverage to address sustainability issues through community participation.
\end{abstract}

Keywords: gross national happiness, sustainable environmental conservation, environmental science, environmental problems, climate change, collectivism

\section{INTRODUCTION}

Gross National Happiness (GNH) is the guiding philosophy of Bhutan's sustainable development process, and sustainable environmental conservation is one of the four pillars of GNH. Bhutan is increasingly experiencing a range of $21^{\text {st }}$ century environmental issues as a result of the socioeconomic development that has changed lifestyles and increased the consumerist behaviours of its people (United Nations Economic Commission for Europe [UNECE], 2016). Environmental degradation (National Education Council [NEC], 2016) is also occurring in response to the increased unsustainable use of natural resources that has resulted from this increased socioeconomic development (Lhamu et al.,
2000). Specific important environmental problems include global climate change, air pollution in urbanised areas, forest degradation, and waste management (NEC, 2016). In a recent study conducted by Chhogyel, Kumar, Bajgai, and Hasan (2020), climate change is predicted to impact the lives of people and decrease food security in Bhutan. Farmers in Bhutan are experiencing the impacts of climate change through loss of crops due to diseases and pests and natural calamities (Chhogyel \& Kumar, 2018). Inadequate waste management has also contributed to water and land pollution, which poses hazards to human health (NEC, 2016). These and other environmental problems have contributed to

Copyright (C) 2022 by Author/s and Licensed by Veritas Publications Ltd., UK. This is an open access article distributed under the Creative Commons Attribution License which permit unrestricted use, distribution, and reproduction in any medium, provided the original work is properly cited. 
habitat loss and human-wildlife conflict across Bhutan (NEC, 2016; Thinley et al., 2018). In addition, flash floods, glacial lake bursts, and landslides are regular occurrences that affect the lives of many people in rural areas (NEC, 2016; Gross National Happiness Commission [GNHC], 2013). These environmental concerns underscore problematic aspects of Bhutan's path to development and the importance of GNH as a developmental philosophy.

Bhutan has had a strong commitment to conservation of the environment for decades but "the same forces that make Bhutan so rich in natural beauty make it relatively poor in those commercially valuable raw materials upon which most national development agendas are based" (NEC, 1998, p. 22). Moreover, at the $15^{\text {th }}$ session of the Conference of Parties (COP15) of United Nation Framework Convention on Climate Change (UNFCCC) held in Copenhagen in 2009, Bhutan committed to remaining carbon neutral for reasons of intergenerational equity (GNHC \& United Nationals Development Programme [UNDP], 2011). To achieve these visions and aspirations, education is considered a key component among a range of efforts to remediate the threats (Dolkar et al., 2013; Dorji et al., 2012). Dolkar et al. (2013) claimed that environmental policies and government acts are inadequate for environmental conservation because although people may possess knowledge about environmental policies and laws, they do not necessarily comply with them. Further, the need to educate Bhutanese youth to respond to the emerging global challenges was emphasised by the Royal Education Council (REC, 2012) potentially at individual level or through collective effort.

Bhutan's vision for peace, prosperity, and happiness is guided by the principles of unity and harmony (GNHC, 1999, p. 8), which permeate Bhutanese culture, including schools. In the cultural context of Bhutan, 'we' signifies the citizens as a collective body that has a strong will and is a source of strength (Tobgye, 2015). Bhutanese people believe that to achieve peace and security, unity and harmony should begin within the family, then extend to the community and the nation (Tobgye, 2015). In the Bhutanese cultural community, unity has been reported in terms of sharing natural resources, such as forest timber and water (Webb \& Dorji, 2004), while collaborative actions among people in communities have contributed to the efficient management of Bhutanese natural resources (Webb \& Dorji, 2004). In the cultural and political context of Bhutan, a new optional Environmental Science (ES) subject in Classes IX-XII was introduced into Bhutanese schools in 2015 "to build a cadre of young people equipped with knowledge, skills and values to engage them in the conservation of natural heritage, promoting sustainable and equitable use of natural resources, preventing all forms of environmental degradation in the pursuit of GNH" (Department of Curriculum Research and Development and Royal Society for the Protection of Nature [DCRD \& RSPN], 2013). The study reported in this paper focused on exploring Environmental Science teachers' and students' perceptions about environmental problems and agentic roles to address environmental issues at the personal and community levels in Bhutan.

\section{LITERATURE REVIEW}

Agency is defined as "understandings about what makes things happen in the social world", and can occur in individuals, in networks of relationships, or in collective groups (Brewer \& Chen, 2007, p. 139). Agency reflects an individual's readiness and competence to engage in taking actions in life (Lipponen \& Kumpulainen, 2011), which is a crucial factor in addressing environmental sustainability in the Bhutanese context. Given the collective nature of Bhutanese society, it is likely that agency in the Bhutanese context may be located in collective groups. In this context, the development of students' strategic and collaborative competencies is important because students can be social change agents and future environmental stewards who can address emerging issues at local, national, and global levels (Schusler \& Krasny, 2010). For example, students could influence the behaviours of others in their homes and communities (Fien et al., 2008), in particular the sustainable consumption behaviours of others (Fien et al., 2008), and could be engaged in decision making to address climate change. Further, Checkoway (2011) asserts that students' active participation in taking action provides opportunities for them to exercise their citizenship rights and contribute to democratic societies. Further, Hayward (2012, p. 195) claims that students should be allowed to "think critically, politically and creatively about their situation, collectively imagine new possibilities, explore how power is exercised in decision-making, and practice strategies to effect community change". To develop and practise agency, they also need to be motivated and free to determine actions for solving environmental issues (Short, 2009). Thus, teachers should avoid making top-down decisions in Education for Sustainable Development (ESD) that would limit students' own decision making (Hayward, 2012, p. 195). While students' active participation in initiating societal change is dependent on their preparedness to act, they also require knowledge, awareness, and practice in the application of action skills and direct experiences that are facilitated and guided by adults (Checkoway, 2011). Environmental awareness and engagement 
with the natural world could be promoted in science by using the natural world as the principal objects of study in the teaching-learning process (Hadzigeorgiou \& Skoumios, 2013, p. 405) and implementing the socio-scientific issues (SSI) approach (Hadzigeorgiou \& Stivaktakis, 2008). The SSI approach is believed to empower students to address issues as it engages them in reflecting on and refining their own ideas about issues by constructing understandings about scientific and social knowledge (e.g., ideas about economics, politics, and ethics), and students may therefore feel empowered to address such issues in their lives (Sadler \& Zeidler, 2009).

However, Jensen (2002) and Jensen and Schnack (1997) believe that teaching knowledge and awareness does not lead to behavioural change with regard to participation in environmental conservation. In order for students to act agentically upon their knowledge and awareness, they require experiences of taking action to solve environmental issues (Jensen, 2004; Jensen \& Schnack, 1997). Therefore, to change students' behaviours, teaching requires that students be engaged in individual or collective activities that are targeted towards solving environmental issues directly or indirectly in the school or the local community (Jensen, 2002; Jensen \& Schnack, 1997). Changing human behaviours to address environmental concerns has been deemed important by Fischer et al. (2012). In the context of Bhutan, Norbu et al. (2017) emphasise the importance of changing the behaviours of the Bhutanese citizens to solve environmental problems. Further, studies have found that change in individual behaviours could have a significant impact on climate change (Edenhofer, 2015), biodiversity conservation (Nielsen et al., 2021), waste management (Minelgaitè \& Liobikienè, 2019), and prevention of pollution (Löhr et al., 2017) and forest fires (Hesseln, 2018). The implication therefore is that for students to act agentically upon their knowledge and awareness, they require experiences with a variety of action skills (Jensen, 2004; Jensen \& Schnack, 1997), such as citizenship, teamwork, and critical thinking skills (Chawla \& Cushing, 2007). Further, they must be cognisant of the values underlying their actions, as previously discussed under the United Nations Educational, Scientific and Cultural Organization (UNESCO)'s socio-emotional domain (Tilbury, 2004). Students also need opportunities to critically and constructively evaluate, reflect, and re-organise their actions to further develop their action competence (Jensen, 2004) and agency.

\section{METHODS}

This paper reports on the qualitative aspects of a mixed method $\mathrm{PhD}$ research project. The research project was conducted to answer the research question: 'What are teachers' and students' views about environmental problems in Bhutan?" The participants were 14 ES teachers and 194 secondary ES students in Classes IX to XII from six secondary schools in the Samtse district of Bhutan, which represented about $30 \%$ of the secondary student population studying ES in the Samste geographical study region. Interviews were conducted to gain indepth understandings of teachers' and students' perceptions about ES teaching and learning. One-onone semi-structured interviews were employed with the ES teachers and focus group interviews were conducted with the students.

For the teachers, the semi-structured individual interviews were adopted to obtain in-depth data (Clark et al., 2021). The semi-structured nature of these interviews provided sufficient flexibility to change the words and sequence of questions and also to probe the responses for clarification or elaboration (Clark et al., 2021). Each interview lasted around 35 minutes. All the interviews were digitally audiorecorded, and the researcher transcribed the audiorecordings verbatim using the computer application InqScribe ${ }^{\mathrm{TM}}$ version 2.2.4.

The focus group interview technique was used for the students because focus groups can bring together participants who share common experiences (Hennink et al., 2020), and promote the collection of a wide range of responses (Clark et al., 2021). It is an efficient form of data collection from a large number of participants and was therefore appropriate for collecting student data. Group situations can also provide participants with the confidence to clearly express and justify their views and opinions (Cohen et al., 2018). As a result, more interaction is likely between the participants and more data can be generated (Cohen et al., 2018). Furthermore, focus groups allow the researcher to explore the diverse views and opinions of all participants (Clark et al., 2021), and also create opportunities for the participants to understand the views of others and critically reflect on their own opinions (Matthews \& Ross, 2014). To obtain as many voices and perspectives as possible, 46 focus group interviews were conducted with the 194 students (Hennink \& Kaiser, 2020). Each focus group had an average of six students and lasted 45 minutes to an hour.

All the interview transcripts were imported into CAQDAS NVivo 12 for in-depth analysis. The interview transcripts were coded by employing both deductive and inductive approaches (Elo \& Kyngäs, 2008) and a constant comparison method (Williams \& Moser, 2019). Throughout this process, coding memos were maintained within NVivo12, as suggested by Jackson and Bazeley (2019). The 
memos noted the developing themes, definitions, ideas, other information, and important verbatim quotations that were evident during coding. Once all the interview data were coded, a matrix coding query was conducted using NVivo12, and the frequency of response to each code was calculated. The results are presented in Tables 1 and 2 and discussed in the results section.

\section{Ethical Considerations}

Ethics approval to conduct this study was provided by the Human Research Ethics Committee of the University of New England, Armidale, Australia, approval number HE17-223. Also, the Bhutan Ministry of Education (MoE) permitted access to the schools to conduct this study.

\section{RESULTS}

The findings on participants' perceptions about environmental problems and agentic roles in environmental conservation are presented and discussed under two themes: views about environmental problems in schools and in Bhutan and views about responsibility for causing and solving environmental problems. In reporting the quotations, the wording is reproduced verbatim with minimum alteration in the language structure. Parenthetical information after each quotation indicates whether it is from a teacher interview $(\mathrm{T}, \mathrm{I})$ or a student focus group (FG).

\section{Views about Environmental Problems in Schools and in Bhutan}

The first theme reflects the perceptions of teachers and students about environmental problems in schools. These are summarised in Table 1.

As shown in Table 1 , waste management in schools was the most frequently mentioned concern for both the teachers and students, being raised as an issue by six teachers and 36 students from 25 focus groups. For example, one of the students mentioned that "the environmental problem we are facing in school is the waste problem" [FG]. Students explained that waste management problems are evident from the litter present in the school. One student stated that "school is not waste-free because we find lots of papers everywhere and we can't finish picking. Still then, we are cleaning every day, but I think people never stop throwing papers" [FG].

The teachers agreed that waste management is a prevalent environmental problem for schools. One teacher suggested that the problem relates to the large number of students, stating that "waste management, I think, is a problem for the school because of large population" [T, I]. One of the teachers also mentioned the challenges faced in disposing of waste in the landfill, stating that "dumping of waste is a problem we faced, again that landfill is a growing problem. It is the size of the waste that increases, and the nearby area is affected" [T, I].

Air pollution was another environmental problem in schools that was reported by one teacher and 17 students from 12 focus groups. For example, students from one school described the impact of factories on the air quality in their locality, claiming that "there are two factories which pollutes air, so we are not getting fresh air" [FG]. Students also identified vehicles and construction as sources of air pollution in schools and mentioned their impact on human health. One student reported that "air pollution due to vehicle and due to construction dust particles people are suffering from cough and cold in winter" [FG]. In addition, students reported the traditional practice of burning waste to be one of the contributors to air pollution in schools. For example, one of the students stated that "we have pit and waste thrown are burnt that causes air pollution" [FG]. One of the teachers from the same school also mentioned

Table 1. Teachers' and Students' Responses About Environmental Problems Identified at Schools

\begin{tabular}{|c|c|c|c|c|}
\hline Sub-theme & Coded response & $\begin{array}{l}\text { Teacher individual } \\
\text { interviews } \\
\mathrm{N}=14\end{array}$ & $\begin{array}{l}\text { No. of students in } \\
\text { focus groups } \\
N=194\end{array}$ & $\begin{array}{l}\text { No. of focus groups } \\
\mathrm{N}=46\end{array}$ \\
\hline \multirow{6}{*}{$\begin{array}{l}\text { Environmental } \\
\text { problems in schools }\end{array}$} & Waste management & 6 & 36 & 25 \\
\hline & Air pollution & 1 & 17 & 12 \\
\hline & Water pollution & & 14 & 13 \\
\hline & Water shortage & 3 & 10 & 8 \\
\hline & Noise pollution & 1 & 7 & 6 \\
\hline & $\begin{array}{l}\text { No environmental } \\
\text { problem }\end{array}$ & 7 & 16 & 10 \\
\hline
\end{tabular}

\footnotetext{
\# Blank cell represents absence of data for the selected code.
} 
the problem of air pollution in school. "The air we breathe in is actually not $100 \%$ clean. We breath in polluted air" [T, I].

Some students from two of the schools also reported the issue of water pollution. For example, students from one of the schools stated "our school surroundings are much cleaner, but water is polluted. It is mixed up with chemicals" [FG], and "the water we drink contains limestone" [FG]. The students also shared the impact of drinking polluted water on their health. For instance, one student mentioned the "water is not clean, and students are suffering from disease like diarrhoea" [FG].

Interestingly, half of the teachers and 16 students from 10 focus groups claimed there were no environmental problems in their school. For example, one of the students explained why they believed there were no environmental issues in their schools:

\section{Our school is not facing environmental problems because we do socially useful productive work (SUPW) in the morning. We have to plant trees and flowers. We have UNESCO and nature clubs. We collect plastic bottles and we are managing our waste. So, no such environmental problems. [FG]}

Similarly, one teacher reported that their school was free from environmental issues, stating that "in school as such, I don't think we have problems related to environment" [T, I]. The teachers who believed there were no environmental problems did so because they had clean air and water and litter-free surroundings because of proper waste disposal. For instance, one teacher mentioned that "we have clean water to drink, clean air to breath, and our school is like litter free, not that we don't produce huge waste but dump at the right designated place" [T, I].

Beyond their school contexts, the teachers and students shared diverse views on the environmental problems in Bhutan, which are outlined in Table 2.

As Table 2 shows, the most frequent problem reported by 35 students from 27 focus groups was forest fire, which they consider to be a major environmental challenge in Bhutan; however, this view was not shared by any of the teachers. The students reported that forest fires are common problems in the country, with one of the students stating that "this year we are facing the problem of forest fires. Like last time there was a forest fire in Paro and frequently in Wangdiphodrang" [FG]. The students suggested that human actions have caused the forest fires in Bhutan, with the statement "I found that forest fire is mostly caused due to human activities" [FG], and also that "forest fire destroys animals, disturbs the ecosystem and imbalanced the ecosystem" [FG].

Thirty-one students from 24 focus groups reported deforestation to be another serious issue in Bhutan, and it is something they often study. One student stated that "we are learning most of the time about the deforestation" [FG], and believed this to be due to socioeconomic development activities. For instance, a student shared that "the forest coverage is decreasing due to modernisation and development of our country" [FG]. The human activities identified by students included "deforestation, mining and road construction" [FG] and illegal extraction of timber for

Table 2. Teachers' and Students' Responses about Environmental Problems Identified in Bhutan

\begin{tabular}{|c|c|c|c|c|}
\hline Sub-theme & Coded response & $\begin{array}{l}\text { Teacher individual } \\
\text { interviews } \\
\mathrm{N}=14\end{array}$ & $\begin{array}{l}\text { No. of students in } \\
\text { focus groups } \\
N=194\end{array}$ & $\begin{array}{l}\text { No. of focus groups } \\
N=46\end{array}$ \\
\hline \multirow{11}{*}{$\begin{array}{l}\text { Environmental } \\
\text { problems of } \\
\text { Bhutan }\end{array}$} & Forest fires & 0 & 35 & 27 \\
\hline & Deforestation & 1 & 31 & 24 \\
\hline & Air pollution & 0 & 27 & 22 \\
\hline & Waste management & 6 & 16 & 16 \\
\hline & Water pollution & 1 & 13 & 10 \\
\hline & Climate change & 4 & 9 & 8 \\
\hline & Loss of biodiversity & 1 & 9 & 6 \\
\hline & Land pollution & 1 & 7 & 7 \\
\hline & Flood & 1 & 4 & 4 \\
\hline & Water shortage & 0 & 3 & 3 \\
\hline & Glacial lake outburst & 2 & 1 & 1 \\
\hline
\end{tabular}


construction and firewood, as "people cut trees without taking anyone's permission. I think this can cause degradation in some places" [FG]. Only one teacher mentioned deforestation as an important problem.

Apart from deforestation, 27 students from 22 focus groups reported air pollution to be a concern in Bhutan. Causes of air pollution they alluded to included rural-urban migration and the increasing number of automobiles. For example, a student reported that "air pollution was mainly because rural to urban migration of people. There are increasing vehicle and people causing air pollution" [FG]. Students anticipate air pollution to be a serious environmental challenge for the future given the increasing socioeconomic development. One of the students shared that "air pollution is predicted to be more dangerous in our country because our country is developing. Researchers found out that after a few years, our air quality will be affected because of factories, industries and increased number of vehicles" [FG].

Waste management was viewed as another environmental issue in Bhutan by 16 students from 16 focus groups, with one student stating that "waste management is the main problem in Bhutan" [FG]. This was the most frequently reported problem by the teachers. One of the teachers reported that "right now, the issue in our country is the waste management" [T, I]. Some students identified people's lack of knowledge about waste management practices to be a cause of this problem, stating that "waste management is an issue. We don't know how to manage our waste" [FG]. Teachers also believed that the problem of waste emerged from a lack of knowledge and inadequate waste segregation. For instance, "Bhutanese people produce more waste and do not segregate. I found waste wherever I go to, office or school. People don't have much knowledge about waste segregation" [T, I].

Climate change is another environmental issue that was identified; however, it was only reported by four teachers and nine students from eight focus groups. One student mentioned that "some of the problems faced by Bhutan are climate change. Climate is changing day by day" [FG]. They pointed to reduced snowfall due to rising global temperatures, which they suggested was caused by "pollution" (it was unclear what kind of pollution), stating that "the climate change is an issue because of pollution. The temperature is rising and there is less snowfall in Thimphu and Paro, because the climate has become hotter than before" [FG].

Also, at least one student reported melting glaciers due to climate change, with "some rapid melting of ice in Himalayas" [FG]. Only four teachers raised the issue that climate change is an issue for Bhutan. One teacher mentioned that "right now, the environmental issue in Bhutan is the climate change" [T, I], and some noted the impact on glaciers, stating that an "environmental problem in Bhutan is climate change and because of global warming, there is melting of glacier on mountains" [T, I].

\section{Views on Responsibility for Causing and Solving Environmental Problems}

The second theme reflects the views of the participants about their responsibility for solving environmental problems. The results are summarised in Table 3.

As evident in Table 3, a quarter of the students from 35 focus groups most often reflected a local focus that the Bhutanese citizens are responsible for causing environmental problems in Bhutan. For instance, "I think, we citizens of the country are responsible for causing environmental problems"

Table 3. Responses Relating to Responsibility for Causing and Solving Environmental Problems in Bhutan

\begin{tabular}{|c|c|c|c|c|}
\hline Sub-theme & Coded response & $\begin{array}{l}\text { Teacher } \\
\text { individual } \\
\text { interviews } \\
\mathrm{N}=14\end{array}$ & $\begin{array}{l}\text { No. of students } \\
\text { in focus groups } \\
\mathrm{N}=194\end{array}$ & $\begin{array}{l}\text { No. of focus } \\
\text { groups } \\
\mathrm{N}=46\end{array}$ \\
\hline \multirow{2}{*}{$\begin{array}{l}\text { Responsibility for } \\
\text { causing environmental } \\
\text { problems }\end{array}$} & Local focus-Bhutanese citizen & & 52 & 35 \\
\hline & Global focus-Human beings & & 24 & 18 \\
\hline \multirow{4}{*}{$\begin{array}{l}\text { Responsibility for } \\
\text { solving environmental } \\
\text { problems }\end{array}$} & Collective responsibility 'We' & 0 & 96 & 33 \\
\hline & Students' responsibilities & 6 & 14 & 11 \\
\hline & $\begin{array}{l}\text { Government organisations and } \\
\text { agencies }\end{array}$ & 0 & 8 & 6 \\
\hline & Individual agency expressed 'I' & 3 & 5 & 5 \\
\hline
\end{tabular}

*Blank cells indicate no data were applicable for this particular code because this question was not posed to teachers 
[FG]. Students claimed that people extracted natural resources, caused forest fires, and did not adequately dispose of waste. "We are responsible for environmental problems because we extract resources from the environment. People are responsible for forest fires" [FG]. About half as many students (24) from 18 focus groups expressed a more global focus of human beings in general being responsible for environmental problems. For example, "We all human beings on earth are responsible for environmental problems" [FG], and "human does things that harm the environment without thinking" [FG].

About a third of the students from 33 focus groups claimed collective responsibility, using 'we' when referring to solving environmental problems; for instance, "we are responsible for solving environmental problems. We alone cannot do everything. Every citizen of our country is responsible for solving the problems" [FG]. This kind of response was far more frequent than any other expressions of responsibility. Also, students mentioned it was their collective responsibility to take concerted action to create awareness in the community for environmental conservation and prevention of environmental problems. "We are responsible for advising people to preserve forest and we have a responsibility for reducing pollutions" [FG].

Aside from this very strong response for collective responsibility, 14 students from 11 focus groups suggested ES students have a particular responsibility to address environmental problems. They stated that "we Environmental Science students have learnt how to protect. So, I think it is our responsibility to take care of the environmental problems" [FG]. A few teachers expected students to create awareness to address environmental problems, stating that "I want children to come forward and create awareness in the community. Maybe through simple awareness campaign" [T, I].

Relatively few (only eight) students from six focus groups identified the responsibility of government agencies to prevent environmental problems through implementation of policies and regulations. For instance, a student claimed "I think it should be the government's responsibility through implementing laws to prevent people from throwing waste. They should impose fine to people if caught cutting down of trees" [FG].

In contrast to the collective responsibility expressed relatively frequently, very few teachers and students from the five focus groups invoked individual responsibility ' $\mathrm{I}$ ' to solve environmental problems. This kind of individual responsibility was evident in the response of students that "I am responsible to prevent environmental problems in the community. I have to advise people who are cutting too much tree or throwing waste in the community" [FG]. Similarly, three teachers indicated their individual responsibility to address environmental problems; for instance, as stated by one teacher, "I have the responsibility to solve environmental problems in school and even at my own home" [T, I].

\section{DISCUSSION}

The students' awareness of various environmental problems in Bhutan may well reflect not only their learning from ES classes but also the influence of social media, which has become available over the past 8 to 10 years and is a popular and novel source of learning about issues and news for Bhutanese people of all ages. Social media is one of the tools used to create environmental awareness in Bhutan (Dolkar et al., 2013), and was identified by Östman (2014) as the primary source through which students acquire knowledge about environmental issues. Social media is considered an effective tool for creating awareness about environmental issues at the local and global levels (Mallick \& Bajpai, 2019).

The students' knowledge of waste and pollution as environmental problems seems to fairly accurately reflect the ineffective waste management practices in Bhutan as identified by the Royal Government of Bhutan (RGoB, 2012). In the community more generally, the waste management infrastructure appears not to be keeping up with the waste being generated by rapid urban development (NEC, 2016). Some participants identified these problems as being an outcome of increased consumption levels by the Bhutanese people, which is consistent with the report by UNECE (2016) that more waste is being generated from readily available pre-packaged commercial commodities due to increased prosperity and a changing throwaway lifestyle in Bhutan. Moreover, Tshomo et al. (2020) claim a lack of knowledge and awareness among the people about effective waste management practices in Bhutan.

Another issue identified by participants in relation to waste management is the problem of air pollution, which accords with another environmental challenge identified by RGoB (2012). Students identified socioeconomic development in their community and the traditional school practice of burning waste as a key contributor to air pollution, as identified in the report by UNECE (2016). That this practice is still occurring despite a reasonable proportion of teachers and students knowing about the issues of burning waste illustrates the knowledge-action gap pointed out by Kollmuss and Agyeman (2002). Also, the persistence of managing waste through the SUPW 
program and burning to remediate daily waste generation may reflect the absence of alternative management options and/or resistance to changing the traditional waste management practices that are not adequate for treatment of wastes like plastics (NEC, 2016). Relevant stakeholders such as the NEC, RSPN, and city corporation may need to collaborate to take bold steps towards establishing appropriate waste management facilities and raising waste management awareness in schools and communities. Further, schools need to work towards changing students' behaviours and developing their social responsibility for conserving the environment through encouraging involvement in community actions to solve issues at schools and in their locality and by taking personal initiatives to change their consumerist behaviours.

The identification by some students that some schools lack a supply of clean drinking water also reflects the challenge of deteriorating water quality raised in the comprehensive Bhutan State of Environment Report (NEC, 2016). According to this report, streams and rivers both in rural and urban areas are polluted by the surface drainage of waste from automobile workshops, greywater, and sewage. Clean drinking water is essential for students' health and wellbeing (Jasper et al., 2012), and schools play a crucial role in ensuring the health and wellbeing of the students, which is one of the nine domains of GNH (Pennock \& Ura, 2011). The schools and their communities may benefit from more effective infrastructure, such as water tanks and water treatment methods like filters, to ensure a supply of clean drinking water for students.

The identification of forest fires and deforestation as significant problems in Bhutan by some students (but not teachers) once again reflects the findings of the Bhutan State of Environment Report (NEC, 2016). Some students suggested that there is a lack of awareness among the people of the impact of forest fires and deforestation on the natural environment, as they are causing the extinction of native flora and fauna (NEC, 2016), are likely to alter the climatic conditions of the relevant areas, and will potentially impact on peoples' livelihoods given the agrarian nature of Bhutanese society. That no teachers mentioned this as an issue may indicate less awareness on the teachers' part of these problems, suggesting the need for teachers' professional development on environmental education that can support their teaching practices and views about the environmental issues (Ernst, 2009).

Importantly, the recurrent outbreak of forest fires and prolonged deforestation may have serious implications for sustainable environmental conservation and the government's commitment to
Bhutan maintaining $60 \%$ forest coverage and remaining carbon neutral in perpetuity (RGoB, 2008). This situation highlights the importance of relevant stakeholders extending their initiatives for creating awareness and citizenship responsibility among the broader community, implementing national forest policy, improving forest road networks (Stefanović et al., 2016), training firefighting forces, improving investigation and surveillance systems, and maintaining safe vegetation coverage to prevent forest fires (Sletnes, 2010).

Of interest, very few participants perceived climate change to be the most significant global environmental challenge being faced in Bhutan (NEC, 2016), despite the learning outcomes in the Environmental Science Curriculum Framework (ESCF) (DCRD \& RSPN, 2013, p. 37), which expect students to:

understand climate change; identify the causes of climate change; explain effects of climate change - global and country level; list the measures for reducing climate change; identify their role in national climate change action plans and initiate measures for reducing climate change and its impacts.

The relative silence from participants about climate change could have been influenced by Bhutan being declared the only carbon-neutral country in the world (NEC, 2016) and the didactic approaches to teaching ineffective in changing the views about climate change (Rousell and Cutter-MackenzieKnowles, 2020). Further, the reasons could be difficulties in understanding climate change by linking it to everyday phenomena because of complexity and lack of climate change discourse that provides a "mental model" (Weber and Stern, 2011). It is associated with several social and environmental factors (Pidgeon and Fischhoff, 2011), such as drought, floods, hurricanes (Spence et al., 2011), melting glaciers, rising earth's temperature and sea levels and flooding (Lorenzoni \& Pidgeon, 2006). Moreover, climate change could be of less concern for many people compared to social issues (see Pidgeon, 2012) due to 'psychological distancing' viewing the issue less threatening and relevant to them (Spence et al., 2012). Further, most people conceive climate change as an issue of concerns impacting the lives of the people on other parts of the world (Lorenzoni \& Pidgeon, 2006). However, the development of students' knowledge, understanding, and awareness about climate change are crucial, given such grave concern for the world. The lack of awareness of climate change in this study indicated inadequacies in 
the preparedness as the future citizen of Bhutan to address the vision and aspirations of achieving GNH through sustainable socio-economic and environmental conservation. Like many other countries, Bhutan remains vulnerable to global climate change affecting its agriculture, hydroelectric power generation, and tourism, which are the areas it relies on for economic development to achieve GNH (NEC, 2016).

Although, the ES textbooks incorporate the three tenets of education about the environment, education for the environment, and education in the environment (DRCD, 2013, p. 12), which are well established in the wider environmental education literature as being relevant for promoting students' awareness about the environment, students appear to lack awareness of environmental issues. This gap could be due to the lack of inclusion of the natural environment as the object of study and their lack of development of a sense of connection to the environment, which is essential for creating environmental awareness. Hadzigeorgiou and Skoumios (2013) claim that teaching about the natural environment or phenomena requires linking directly to the natural environment to promote awareness. Teaching without a connection to the environment may very well result in students comprehending an environmental issue, but they may not become aware that they are a part of it (Hadzigeorgiou \& Stivaktakis, 2008). This approach could promote a dichotomy between learners and Nature that conflicts with the ideas of self-as-part-ofNature and respect for Nature (Hadzigeorgiou \& Stivaktakis, 2008, p. 411). This continued "empirical treatment of the natural world perpetuates the dichotomy between self and Nature, then, one might argue, the development of environmental awareness is discouraged" (p. 411).

Further, the lack of awareness could result from teachers' over reliance on traditional and scientific approaches, such as the "activity-based approach including indoor, outdoor activities, hands on experiences, experiments, case studies, surveys, debates, discussion, teamwork, folk art and so on" recommended in the ESCF (DCRD, 2013, p.18). Hadzigeorgiou and Stivaktakis (2008) claim that such inquiry approaches that use process skills are critical in science education, but they cannot build environmental awareness on their own because they do not create an awareness of being part of the natural world.

Therefore, to teach effectively about the environment in ES, it is necessary to create students' awareness by assisting them to understand that they are part of their local environmental issues and that there are also wider implications for the global environmental challenges, which will develop their sense of connection to nature (Hadzigeorgiou \& Stivaktakis, 2008). The implementation of a socioscientific issues (SSI) approach to teaching about environmental issues could be effective in creating student's awareness. The SSI approach (Hadzigeorgiou \& Stivaktakis, 2008) contextualizes the issues and engages students in reflecting on the interrelationships between the physical and social worlds and the moral values that govern their decision making in connection to socio-scientific concerns (Zeidler \& Nichols, 2009).

It is to some extent encouraging that a quarter of the students did acknowledge the role of Bhutanese citizens in contributing to Bhutan's environmental problems. All citizens, including students, need to understand that they contribute to the environmental problems facing the country. They need to identify and understand that their actions and consumerist behaviours contribute to environmental problems at all levels.

The collective responsibility 'we' referred to by many students to solve environmental problems in Bhutan seems likely to reflect the location of agency in collective groups (Brewer \& Chen, 2007), which is consistent with Bhutanese cultural belief about the joint actions of citizens being the source of strength and power for attaining the common goals and aspirations of the country (Dorji \& Webb, 2003; RGoB, 2012; Tobgye, 2015). Collectivism is a real potential strength in terms of students' participations in taking action. This collective perspective is a cause for optimism for Bhutan's environmental future given the argument by Clowney (2014) that:

It is we collectively as well as individually who cause the environmental problems and they will not be solved by the action of individual alone. They need collective solutions that also address the relationship between the individual and collective character and responsibility. (p. 317)

The importance of collective actions to achieve sustainability at all levels has been recognised by UNESCO (2017). Moreover, it has been argued that people who have a collectivist perspective focus less on personal benefits and are more likely to participate in taking action to solve environmental problems than people who have an individual focus (McCarty \& Shrum, 2001, p. 95).

On the other hand, the fact that only five students expressed individual responsibility for solving environmental problems raises the question of whether there are potential negative implications of the location of agency in the collective rather than the 
individual in Bhutan. If the unity that is espoused and aspired to in Bhutan is not achieved, then it may be that people may not act at the individual level to solve the environmental problems in the country.

\section{CONCLUSION AND IMPLICATIONS}

The teachers' and students' lack of knowledge and awareness about climate change issues suggests the need for more emphasis on climate change education in Bhutan. Given the serious climate change concerns globally, GNHC and UNDP (2011) recommend incorporating climate change education into the school curriculum to equip students with the knowledge and skills to play the role of change agents in their communities to address environmental problems. Therefore, the apparent limited student awareness of climate change is an area that requires further attention in ES and in other school subjects for students who do not elect to study ES. It is crucial to educate every student with the knowledge, awareness, and skills to address and respond to climate change at the national and global level. This emphasis is particularly important given the magnitude of the future challenges posed by climate change globally and to the Bhutan in achieving the aspirations of the Middle Path to GNH through sustainable environmental conservation and sustainable socio-economic development.

\section{ACKNOWLEDGEMENTS}

Author thanks Dr Frances Quinn, Dr Sue Elliot and Prof. Neil Taylor from the School of Education, University of New England, Australia, for their guidance in writing and completion of the $\mathrm{PhD}$ thesis and the University for providing an IPRA scholarship.

\section{REFERENCES}

Brewer, M. B., \& Chen, Y.-R. (2007). Where (who) are collectives in collectivism? Toward conceptual clarification of individualism and collectivism. Psychological Review, 114(1), 133-151. https://doi.org/10.1037/0033-295X.114.1.133.

Chawla, L., \& Cushing, D. F. (2007). Education for strategic environmental behavior. Environmental Education Research, 13(4), 437-452. https://doi.org/10.1080/13504620701581539.

Checkoway, B. (2011). What is youth participation? Children and Youth Services Review, 33(2), 340345.

Chhogyel, N., \& Kumar, L. (2018). Climate change and potential impacts on agriculture in Bhutan: A discussion of pertinent issues. Agriculture \& Food Security, 7(1), 79. https://doi.org/10.1186/s40066-018-0229-6.

Chhogyel, N., Kumar, L., Bajgai, Y., \& Hasan, M. K. (2020). Perception of farmers on climate change and its impacts on agriculture across various altitudinal zones of Bhutan Himalayas. International Journal of Environmental Science and Technology, 17(8), 3607-3620. https://doi.org/10.1007/s13762-020-02662-8 .

Clark, T., Foster, L., Sloan, L., \& Bryman, A. (2021). Social Research Methods 6E, Oxford University Press.

Clowney, D. (2014). Collective environmental virtue. Environmental Values, 23(3), 315-333. https://doi.org/10.3197/096327114X1394790018 1194.

Cohen, L., Manion, L., \& Morrison, K. (2018). Research methods in education. Routledge.

Department of Curriculum Research and Development \& Royal Society for the Protection of Nature. (2013). Environmental science curriculum framework: Classes PP-XII. Ministry of Education.

Dolkar, J., Dorji, S., Dorji, T., Choden, K., Wangmo, N., \& Patel, S. S. (2013). Public awareness of environmental policies in Bhutan. Bhutan Journal of Research and Development, 1-13.

Dorji, S., Rajaratnam, R., \& Vernes, K. (2012). The vulnerable Red Panda in Bhutan: Distribution, conservation status and management recommendations. Oryx, 46(4), 536-543. https://doi.org/10.1017/S0030605311000780.

Edenhofer, 0. (2015). Climate change 2014: mitigation of climate change (Vol. 3): Cambridge.

Elo, S., \& Kyngäs, H. (2008). The qualitative content analysis process. Journal of Advanced Nursing, 62(1), 107-115. https://doi.org/10.1111/j.13652648.2007.04569.x.

Ernst, J. (2009). Influences on U.S. middle school teachers' use of environment-based education. Environmental Education Research, 15(1), 71-92.

Fien, J., Neil, C., \& Bentley, M. (2008). Youth can lead the way to sustainable consumption. Journal of Education for Sustainable Development, 2(1), 5160. https://doi.org/10.1177/097340820800200111.

Fischer, J., Dyball, R., Fazey, I., Gross, C., Dovers, S., Ehrlich, P. R., ... Borden, R. J. (2012). Human behavior and sustainability. Frontiers in Ecology and the Environment, 10(3), 153-160.

Gross National Happiness Commission. (1999). Bhutan 2020: A vision for peace, prosperity and happiness. http://www.gnhc.gov.bt/wpcontent/uploads/2011/05/Bhutan2020_2.pdf

Gross National Happiness Commission [GNHC] (2013). Eleventh five year plan: Main document.

Gross National Happiness Commission \& United Nations Development Programme. (2011). Bhutan national human development report: Sustaining progress: Rising to the climate challenge. https://planipolis.iiep.unesco.org/en/2011/bhutan -human-development-report-2011-sustainingprogress-rising-climate-challenge-5179 
Hadzigeorgiou, Y., \& Stivaktakis, S. (2008).

Encouraging involvement with school science.

Journal of Curriculum and Pedagogy, 5(1), 138-162.

Hadzigeorgiou, Y., \& Skoumios, M. (2013). The development of environmental awareness through school science: Problems and possibilities.

International Journal of Environmental and Science Education, 8(3), 405-426.

Hayward, B. (2012). Children, citizenship and environment: Nurturing a democratic imagination in a changing world. Routledge.

Hennink, M., Hutter, I., \& Bailey, A. (2020). Qualitative research methods: Sage.

Hennink, M. M., \& Kaiser, B. N. (2020). Saturation in qualitative research. Sage.

Hesseln, H. (2018). Wildland fire prevention: A review. Current Forestry Reports, 4(4), 178-190.

Jackson, K., \& Bazeley, P. (2019). Qualitative data analysis with NVivo: Sage.

Jasper, C., Le, T.-T., \& Bartram, J. (2012). Water and sanitation in schools: A systematic review of the health and educational outcomes. International Journal of Environmental Research and Public Health, 9(8), 2772-2787. https://doi.org/10.3390/ijerph9082772.

Jensen, B. B. (2002). Knowledge, action and proenvironmental behaviour. Environmental Education Research, 8(3), 325-334. https://doi.org/10.1080/13504620220145474.

Jensen, B. B. (2004). Environmental and health education viewed from an action-oriented perspective: A case from Denmark. Journal of Curriculum Studies, 36(4), 405-425. https://doi.org/10.1080/0022027032000167235.

Jensen, B. B., \& Schnack, K. (1997). The action competence approach in environmental education. Environmental Education Research, 3(2), 163-178. https://doi.org/10.1080/1350462970030205.

Kollmuss, A., \& Agyeman, J. (2002). Mind the gap: Why do people act environmentally and what are the barriers to pro-environmental behavior? Environmental Education Research, 8(3), 239-260. https://doi.org/10.1080/13504620220145401.

Lhamu, C., Rhodes, J. J., \& Rai, D. (2000). Integrating economy and environment: The development experience of Bhutan. In M. Banskota, T. S. Papola, J. Richter (Eds.), Growth, poverty alleviation and sustainable resource management in the mountain areas of South Asia (pp. 137-170). International Centre for Integrated Mountain Development.

Lipponen, L., \& Kumpulainen, K. (2011). Acting as accountable authors: Creating interactional spaces for agency work in teacher education. Teaching and teacher education, 27(5), 812-819.

Löhr, A., Savelli, H., Beunen, R., Kalz, M., Ragas, A., \& Van Belleghem, F. (2017). Solutions for global marine litter pollution. Current opinion in environmental sustainability, 28, 90-99.
Lorenzoni, I., \& Pidgeon, N. F. (2006). Public views on climate change: European and USA perspectives. Climatic change, 77(1), 73-95.

Mallick, R., \& Bajpai, S. P. (2019). Impact of social media on environmental awareness. In Narula, S., Rai, S., \& Sharma, A. (Eds.), Environmental awareness and the role of social media (pp. 140149). IGI Global.

Matthews, B., \& Ross, L. (2014). Research methods. Longman/Pearson Education.

McCarty, J. A., \& Shrum, L. (2001). The influence of individualism, collectivism, and locus of control on environmental beliefs and behavior. Journal of Public Policy \& Marketing, 20(1), 93-104.

Minelgaitè, A., \& Liobikienè, G. (2019). Waste problem in European Union and its influence on waste management behaviours. Science of The Total Environment, 667, 86-93.

National Environment Commission [NEC] (1998). The middle path: National environment strategy for Bhutan. http://www.nec.gov.bt/resources/

National Environment Commission. (2016). Bhutan state of the environment report 2016.

http://www.nec.gov.bt/nec1/wpcontent/uploads/2016/07/Bhutan-State-ofEnvironment-Report-2016.pdf

Nielsen, K. S., Marteau, T. M., Bauer, J. M., Bradbury, R. B., Broad, S., Burgess, G., ... Espelosin, D. (2021). Biodiversity conservation as a promising frontier for behavioural science. Nature Human Behaviour, 5(5), 550-556.

Norbu, G., Tobgay, T., Dorji, K., Peday, T., \& Wangmo, D. (2017). Behaviour change strategy for better waste management in Thimphu City. Thimphu Thromde Management.

http://www.thimphucity.bt/downloads/behaviourchange-strategy-better-waste-managementthimphu-city

Östman, J. (2014). The influence of media use on environmental engagement: A political socialization approach. Environmental Communication, 8(1), 92109.

Pennock, M., \& Ura, K. (2011). Gross national happiness as a framework for health impact assessment. Environmental Impact Assessment Review, 31(1), 61-65. https://doi.org/10.1016/j.eiar.2010.04.003.

Pidgeon, N. (2012). Public understanding of, and attitudes to, climate change: UK and international perspectives and policy. Climate Policy, 12(sup01), S85-S106.

Pidgeon, N., \& Fischhoff, B. (2011). The role of social and decision sciences in communicating uncertain climate risks. Nature climate change, 1(1), 35-41.

Rousell, D., \& Cutter-Mackenzie-Knowles, A. (2020). A systematic review of climate change education: Giving children and young people a 'voice'and a 'hand'in redressing climate change. Children's Geographies, 18(2), 191-208. 
Royal Education Council [REC] (2012). The national education framework: Shaping Bhutan's future.

RGoB. (2008). The Constituion of Kingdom of Bhutan. Royal Government of Bhutan.

https://www.gov.bt/constitution-of-bhutan/

RGoB. (2012). In pursuit of sustainable dvelopment: National report for the United Nation Conference on Sustainable Development. Royal Government of Bhutan.

Sadler, T. D., \& Zeidler, D. L. (2009). Scientific literacy, PISA, and socioscientific discourse: Assessment for progressive aims of science education. Journal of Research in Science Teaching, 46(8), 909-921.

Schusler, T. M., \& Krasny, M. E. (2010). Environmental action as context for youth development. Journal of Environmental Education, 41(4), 208-223. https://doi.org/10.1080/00958960903479803.

Short, P. C. (2009). Responsible environmental action: Its role and status in environmental education and environmental quality. Journal of Environmental Education, 41(1), 7-21. https://doi.org/10.1080/00958960903206781.

Sletnes, A. (2010). Assessment of Forest Fire Risks and Innovative Strategies for Fire Prevention. Paper presented at the Ministerial Conference on the Protection of Forests in Europe.

Stefanović, B., Stojnić, D., \& Danilović, M. (2016). Multicriteria forest road network planning in fire-prone environment: a case study in Serbia. Journal of Environmental Planning and Management, 59(5), 911-926.

Spence, A., Poortinga, W., Butler, C., \& Pidgeon, N. F. (2011). Perceptions of climate change and willingness to save energy related to flood experience. Nature Climate Change, 1(1), 46-49.

Spence, A., Poortinga, W., \& Pidgeon, N. (2012). The psychological distance of climate change. Risk Analysis: An International Journal, 32(6), 957-972.

Thinley, P., Rajaratnam, R., Lassoie, J. P., Morreale, S. J., Curtis, P. D., Vernes, K., Leki, L., Phuntsho, S., Dorji, T., \& Dorji, P. (2018). The ecological benefit of tigers (Panthera tigris) to farmers in reducing crop and livestock losses in the eastern Himalayas: Implications for conservation of large apex predators. Biological Conservation, 219, 119-125.

Tilbury, D. (2004). Rising to the challenge: Education for sustainability in Australia. Australian Journal of Environmental Education, 20(2), 103-114.

Tobgye, S. (2015). The Constitution of Bhutan: Principles and philosophies. Bhutan National Legal Institute.

Tshomo, U., Dorji, C., \& Dahal, Y. (2020). Integrated waste management in Bhutan. In Ghosh, S. K. (Ed.). Circular Economy: Global Perspective (pp. 67-86): Springer.

United Nations Economic Commission for Europe [UNECE] (2016). Ten years of the UNECE strategy for education for sustainable development: Evaluation report on the implementation of the
UNECE strategy for education for sustainable development from 2005 to 2015. United Nations.

United Nations Educational, Scientific and Cultural Organization [UNESCO] (2017). Education for sustainable development goals: Learning objectives. https://unesdoc.unesco.org/ark:/48223/pf000024 7444

Webb, E. L., \& Dorji, L. (2004a). The evolution of forestrelated institutions in Bhutan. Asian Institute of Technology.

Weber, E. U., \& Stern, P. C. (2011). Public understanding of climate change in the United States. American Psychologist, 66(4), 315.

Williams, M., \& Moser, T. (2019). The art of coding and thematic exploration in qualitative research. International Management Review, 15(1), 45-55.

Zeidler, D., \& Nichols, B. (2009). Socioscientific issues: Theory and practice. Journal of Elementary Science Education, 21, 49-58. 